\title{
The chemical composition, fermentation profile, and microbial populations in tropical grass silages
}

\author{
João Paulo Sampaio Rigueira', Odilon Gomes Pereira', Karina Guimarães Ribeiro', Hilário \\ Cuquetto Mantovani ${ }^{1}$, Mariele Cristina Nascimento Agarussi ${ }^{1}$
}

${ }^{1}$ Universidade Federal de Viçosa (UFV).

\begin{abstract}
The objective of this study was to evaluate the fermentation profile, chemical composition and microbial population and losses in the silages of signalgrass and Mombasa grass fertilized with the following levels of nitrogen (N): 0,30 , 60 and $90 \mathrm{~kg} / \mathrm{ha}$. The grasses were harvested at 70 days of regrowth, chopped and then ensiled in laboratory silos that had $20 \mathrm{~kg}$ of capacity and a snap-top cover and were fitted with Bunsen valves. Before ensiling, samples of the plants were used for the isolation and identification of lactic acid bacteria (LAB) in epiphytic microbiota. The design adopted was a $4 \times 2$ factorial arrangement, with four doses of $\mathrm{N}$ and two forage species, in a completely randomized design, with four replicates. The predominant species of LAB was Lactobacillus fermentum. The interaction between the $\mathrm{N}$ dose and forage species affected the dry matter (DM), crude protein (CP), neutral detergent fiber (NDF), acid detergent fiber (ADF) and water soluble carbohydrates (WSC) of the silages. The $\mathrm{pH}$ values and gas losses were influenced only by the forage species, with higher values for the Mombasa grass. For the ammonia $\left(\mathrm{NH}_{3}-\mathrm{N}\right)$ levels and effluent losses, there was an effect of the interaction between the forage species and $\mathrm{N}$ doses, and the highest values of $\mathrm{NH}_{3}-\mathrm{N}$ and effluent losses were found in the Mombasa grass silage fertilized with $60 \mathrm{~kg} \mathrm{~N} / \mathrm{ha}$. Nitrogen fertilization reduces the levels of DM and WSC in the silages and also increases the levels of CP, $\mathrm{NH}_{3}-\mathrm{N}$ and effluent losses.
\end{abstract}

Key Words: ammonia, effluent, lactic acid bacteria, $\mathrm{pH}$

\section{Introduction}

The excess forage produced by the perennial species in the rainy season must be conserved and should be considered a potential forage resource for feed in the dry season.

Grass silages of the genus Panicum and signalgrass have constituted two of the most widely used roughages in the feedlots of Brazil. In 2006, data indicate that grass silages were used by $18 \%$ of the 50 largest beef cattle feedlots in Brazil (Agripoint, 2007).

The grass silages have some interesting advantages, such as a high annual productivity per area, perenniality, a low risk of loss, and greater harvest flexibility (Gonçalves et al., 2004). However, when compared with corn or sorghum silages, the grass silages also have unfavorable aspects, such as a low content of soluble carbohydrates necessary for proper fermentation, low dry matter content at the time of cutting, high buffering capacity and lower energy content (Keady et al., 2008). Detailed evaluations have indicated that a kilogram of total digestible nutrients (TDN) from grass silage is more expensive than TDN from corn silage (Pereira et al., 2007). Thus, tropical grasses are only an attractive option if they are highly productive. Assuming that the potential for biomass production must be achieved, the use of nitrogen can be a viable alternative for enhancing the production of dry matter.

Nitrogen is considered to be the nutrient that causes the greatest response in the development and production of forage plants. According to Colozza et al. (2000), several studies have demonstrated significant increases in dry matter production and the nutritional value of Panicum maximum with nitrogen supply. Although there was a linear response to nitrogen in most of these studies, the magnitude of these responses was different.

Although the existing literature provides a large amount of information concerning effects of nitrogen on the productivity and nutritional value of produced forage, there is little information on the ways that nitrogen fertilization affects the fermentation profile, the native microorganism population, and losses during fermentation in tropical forage species.

The objective of this study is to characterize and to quantify the microbial populations and to evaluate the fermentation characteristics and the chemical composition of silage produced from signalgrass and Mombasa grass grown under different doses of nitrogen. 


\section{Material and Methods}

The experiment was conducted in different areas of pastures of Panicum maximum cv. Mombasa and of Brachiaria decumbens cv. Basilisk. The chemical analyses of forage and silage, as well as the isolation and identification of the lactic acid bacteria, were performed in the Forage Laboratory of the Animal Science Department of Universidade Federal de Viçosa, located in Viçosa, Minas Gerais, Brazil.

The local soil is classified as Yellow Red Argisol and has a clay loam texture. Prior to the beginning of the experiment, soil sampling was performed in the 0 to $20 \mathrm{~cm}$ depth layer in all plots of the experimental area to monitor soil fertility. Because of the chemical analysis of the soil samples, there was no need for $\mathrm{pH}$ correction. To standardize the height and growth of the forage, a uniform cut was performed on the grass throughout the experimental area in December 2008. Eight plots measuring $200 \mathrm{~m}^{2}$ each were delimited; there were four plots for each grass species. The nitrogen doses were then applied according to the following treatments: $0,30,60$ and $90 \mathrm{~kg} / \mathrm{ha}$, with a dose of $60 \mathrm{~kg} / \mathrm{ha}$ of $\mathrm{K}_{2} \mathrm{O}$ applied to each plot. Ammonium sulfate and potassium chloride were used as sources of nitrogen and potassium, respectively.

Using a backpack mower, the plants were harvested at 70 days of regrowth and then chopped on a stationary silage machine. The forage was ensiled in buckets with a capacity of $20 \mathrm{~kg}$. A total of 32 buckets were fitted with a Bunsen valve in the cap for the exhaustion of gases, and there were four replicates of each treatment. At the bottom of the buckets, $4 \mathrm{~kg}$ of sand were placed in cotton fabric bags to capture the effluent. To quantify the losses of dry matter by gases, the buckets were weighed after ensiling and at the time of opening. The experimental silos were kept at room temperature in a covered area, and opened 90 days after closure. The compaction of the material was performed with the feet, aiming at a density of $350 \mathrm{~kg} / \mathrm{m}^{3}$.

A $4 \times 2$ factorial arrangement was used in a completely randomized design (CRD) with four nitrogen doses $(0$, 30,60 and $90 \mathrm{~kg} / \mathrm{ha}$ ), the silages of two forage species (P. maximum cv. Mombasa and B. decumbens), and four replications.

The pre-drying of the fresh grasses and their respective silages was performed in a convection oven at $60^{\circ} \mathrm{C}$ for 72 hours. The grasses were then ground on a Willey mill with a $1 \mathrm{~mm}$ sieve and stored in polyethylene plastic vials for subsequent laboratory analyses. The dry matter (DM) and crude protein (CP) of the ground samples were determined according to techniques described by Silva $\&$
Queiróz (2002). The neutral detergent fiber (NDF) and acid detergent fiber (ADF) were determined according to Van Soest \& Robertson (1985).

To measure the $\mathrm{pH}, 25 \mathrm{~g}$ of silage samples were homogenized in $225 \mathrm{~mL}$ of phosphate buffer (Ringer Solution) - sodium chloride $(2.25 \mathrm{~g} / \mathrm{L})$, potassium chloride $(0.105 \mathrm{~g} / \mathrm{L})$, anhydrous calcium chloride $(0.12 \mathrm{~g} / \mathrm{L})$, sodium bicarbonate $(0.05 \mathrm{~g} / \mathrm{L})$ and sodium thiosulfate $(0.25 \mathrm{~g} / \mathrm{L})$ for one minute in a blender. To obtain the aqueous extract, this mixture was then filtered through a Whatman Grade 54 paper filter, and the $\mathrm{pH}$ was immediately red on a digital $\mathrm{pH}$ meter (DM-23, Digimed).

For the determination of the ammonia nitrogen, $200 \mathrm{~mL}$ of a $2 \mathrm{~N} \mathrm{H}_{2} \mathrm{SO}_{4}$ solution were added to $25 \mathrm{~g}$ of silage that had been stored in a refrigerator for 48 hours. After filtration on filter paper, the $\mathrm{N}-\mathrm{NH}_{3}$ concentration was determined by titration with weak acid according to the methodology described by Bolsen et al. (1992).

The water soluble carbohydrate (WSC) contents were determined according to the methodology described by Johnson et al. (1966).

The bacteria of Lactobacillus genus in the grasses before silage were isolated and identified. The samples were collected randomly from the different grass species and nitrogen doses, and then a composite sample was prepared for each forage species, which were then immediately taken to the laboratory for analyses.

In an industrial blender, $25 \mathrm{~g}$ of forage and $225 \mathrm{~mL}$ of sterile phosphate buffer solution were mixed for one minute. Decimal dilutions from $10^{-1}$ to $10^{-7}$ were made, with plating in duplicate in Rogosa agar (Difco) and incubation at $37{ }^{\circ} \mathrm{C}$ for 48 hours. From the higher elevated dilutions, a number of colonies were selected, equivalent to the square root of the total of colony-forming units (cfu), observed in the plates. This procedure was performed to select the predominant strains the medium.

The colonies selected from the higher dilutions were cultivated in MRS broth (Difco ${ }^{\circledR}$; De Man et al., 1960) at $37^{\circ} \mathrm{C}$ for 48 hours. Two simple isolation streaks were then performed in a solid medium MRS Agar (Difco ${ }^{\circledR}$; De Man et al., 1960) for the isolation and purification of isolated cultures. The tests of gram coloration and of reaction to the enzyme catalase were performed. For subsequent identification testing, the rod-shaped, Gram-positive, and catalase-negative cultures were recultivated in MRS broth (Difco ${ }^{\circledR}$; De Man et al., 1960).

The LAB isolates in the grass samples were identified with a fermentation profile of 49 carbohydrates of the API CH 50 kit (BioMeurix - France). Four pure cultures from the signalgrass and six cultures from the Mombasa grass 
with similar morphology (both catalase negative and Gram positive) were subjected to three successive activations. The trays were incubated at $37{ }^{\circ} \mathrm{C}$ in a BOD oven, and carbohydrate fermentation tests were read at 24 and $48 \mathrm{~h}$ by a color change from blue to yellow. Identification was performed using the API software (Bio Meurix - France), which expresses the result in a percentage identity according to the standard use of sugars by the inoculated bacteria.

Isolate growth tests were performed under different $\mathrm{pH}$ values (9.6 and 7.2) and at temperatures of 15 and $45{ }^{\circ} \mathrm{C}$. Trypic Soy Broth (TSB) adjusted to 7.2 and 9.6 was used for the growing test. The isolates were also incubated at 15 and $45{ }^{\circ} \mathrm{C}$ in an MRS broth. After 24 hours of incubation, we observed whether there was growth under these different conditions by measuring the turbidity of the media.

The microbial populations were quantified using the following selective cultures for each microbial group: Rogosa agar (Difco), for LAB count; violet red bile (Difco) with overlying, for enterobacteria count; and potato dextrose agar (PDA), for count of fungi and yeasts.

The dry matter losses in the silages in the forms of gases and effluents were quantified by weight difference according to Cai \& Ohmomo (1995).

The evaluation of data was performed by an analysis of variance at $5 \%$ significance using the SISVAR program (Ferreira, 2000). For the qualitative factor (forage species), the $\mathrm{F}$ test was used. A regression analysis was performed for the quantitative factor (doses of $\mathrm{N}$ ). The interaction (dose of $\mathrm{N} \times$ forage species) was deployed when significant at a $5 \%$ probability.

\section{Results and Discussion}

The dry matter (DM) content of the plants before ensiling ranged from $16.1 \%$ to $22.6 \%$ (Table 1). The lowest DM content in the Mombasa grass fertilized with $60 \mathrm{~kg}$ $\mathrm{N} /$ ha was likely due to methodological errors.

The DM content is critical for the production of good quality silages; however, there have been large variations in the values of grasses collected at the same age of regrowth in different locations. These variations indicate that the age of regrowth is not an adequate feature to determine the cutting time in tropical forages for silage because other factors, such as soil fertility, rainfall, and solar radiation, have a major effect on the DM content of forage plants. Thus, to determine the proper time to cut and ensilage, the height of the plant might be an interesting factor to be evaluated along with the regrowth age (Magalhães et al. 2006).

In both forages, there was an increase in the crude protein content with higher $\mathrm{N}$ doses. This increase is due to the greater availability of $\mathrm{N}$ in the soil, which favors the absorption and accumulation of $\mathrm{N}$ in plant tissues. Another possible factor for the increase is that the applied nitrogen might have favored plant tillering and, consequently, increased the leaf proportion. Since the CP content of the leaves is higher than in other plant tissues, the increase in $\mathrm{CP}$ content with higher doses of $\mathrm{N}$ is justified.

Keady et al. (2000) observed an increase in CP when increasing the dose from 72 to $168 \mathrm{~kg} \mathrm{~N} / \mathrm{ha}$ in grasses. Similar behavior was observed by Keady \& O'Kiedk (1996, 1998). The concentrations of NDF and ADF indicated that there were no major variations in the fiber contents with higher nitrogen doses. The absence of change in the NDF content due to nitrogen fertilization was also observed by Wilman (1975) and Wilman et al. (1976). The similar values of these components with different doses of $\mathrm{N}$ suggest that the $\mathrm{N}$ mainly favored the tillering of the plant over height growth. If the increased production of DM had been given by the vertical growth of plants, the plants would possibly have a higher proportion of fiber needed for their support (Johnson et al. 2001).

The content of WSC ranged from $28.3 \mathrm{~g} / \mathrm{kg}$ in Mombasa grass at the dose of $60 \mathrm{~kg} / \mathrm{ha}$ to $44.7 \mathrm{~g} / \mathrm{kg}$ in signalgrass at the dose of $30 \mathrm{~kg} / \mathrm{ha}$. Keady \& Mayne (1996) and Wilson (1969) observed a decrease in soluble carbohydrates and a higher buffering capacity with increasing doses of $\mathrm{N}$ applied to grasses. Reduction in the concentration of WSC with higher doses of $\mathrm{N}$ was also observed by Keady et al. (2000) and Namihira et al. (2009). The increased translocation of WSC for the growth of treated plants provides a possible explanation for this result. According to Alexandrino et al.

Table 1 - Chemical composition of Mombasa grass and signalgrass plants fertilized with different doses of nitrogen

\begin{tabular}{|c|c|c|c|c|}
\hline \multirow{2}{*}{ Grasses } & \multicolumn{4}{|c|}{ Doses of nitrogen $(\mathrm{kg} / \mathrm{ha})$} \\
\hline & 0 & 30 & 60 & 90 \\
\hline & \multicolumn{4}{|c|}{ Dry matter $(\mathrm{g} / \mathrm{kg})$} \\
\hline Mombasa & 195.2 & 211.2 & 160.8 & 225.8 \\
\hline \multirow[t]{2}{*}{ Signalgrass } & 213.6 & 211.4 & 203.5 & 216.0 \\
\hline & \multicolumn{4}{|c|}{ Crude protein (g/kg DM) } \\
\hline Mombasa & 54.7 & 53.2 & 60.2 & 67.5 \\
\hline \multirow[t]{2}{*}{ Signalgrass } & 55.5 & 52.7 & 58.9 & 60.2 \\
\hline & \multicolumn{4}{|c|}{ Neutral detergent fiber (g/kg DM) } \\
\hline Mombasa & 714.8 & 686.7 & 727.6 & 715.2 \\
\hline \multirow[t]{2}{*}{ Signalgrass } & 704.7 & 728.3 & 717.0 & 734.7 \\
\hline & \multicolumn{4}{|c|}{ Acid detergent fiber (g/kg DM) } \\
\hline Mombasa & 369.8 & 344.2 & 407.3 & 365.8 \\
\hline \multirow[t]{2}{*}{ Signalgrass } & 348.8 & 377.9 & 380.0 & 384.6 \\
\hline & \multicolumn{4}{|c|}{ Water soluble carbohydrates (g/kg DM) } \\
\hline Mombasa & 38.6 & 37.7 & 28.3 & 31.4 \\
\hline Signalgrass & 36.0 & 44.7 & 31.1 & 33.9 \\
\hline
\end{tabular}


(2008), if the applied nitrogen allows for plant growth, then the tendency is to use the available carbohydrates to form cells and protoplasm instead of causing the thickening of the cell walls by the accumulation of these carbohydrates, which would cause a reduction in the content of WSC in the plant.

The soluble carbohydrate content is critical for the production of good quality silage because it is the main source of nutrients for the growth of microorganisms that produce lactic acid. McDonald et al. (1991) suggested that the potential of a plant for silage depends on the content of WSC, with desired levels above $8 \%$ in DM. However, it is well known that tropical grasses have a low content of soluble carbohydrates.

An effect $(\mathrm{P}<0.05)$ of the interaction of the dose of $\mathrm{N}$ and forage species was observed on the contents of DM, CP, NDF, ADF and WSC of the silages (Table 2). The lowest DM content observed in the silage of Mombasa grass fertilized with $60 \mathrm{~kg} / \mathrm{ha}$ is explained by the lower DM content of the plant at the time of ensiling. Compared with fresh plants, there was a higher content of dry matter in silages, except in nitrogen doses of $90 \mathrm{~kg} / \mathrm{ha}$. This is possibly due to a loss of water because of leaching during fermentation. Furthermore, the loss of nutrients due to secondary fermentation can also contribute to an increase in the DM contents relative to the original forage. Similar behavior was observed in the silages of Marandu grass (Bernardes, 2006; Cezário, 2011) and timothy grass (Phleum pretense) (Pauly et al., 1999).

There was a linear effect of the doses of $\mathrm{N}$ on the DM contents of the silages of Mombasa and signalgrass, with estimated reductions of 0.0345 and 0.0243 percentage units of DM per kilogram of applied nitrogen, respectively. Reductions in the DM contents in grass silages with increasing $\mathrm{N}$ doses were also observed by Keady et al. (1995) and Keady \& O'Kiely $(1996,1998)$. Nitrogen increases the succulence of the plants, which causes the plants fertilized with $\mathrm{N}$ to have a higher water content than non-fertilized plants (Magalhães et al. 2011).

Except for the plants not fertilized with $\mathrm{N}$, there was a higher content of $\mathrm{CP}$ in the silage of Mombasa grass than in the silage of signalgrass. Santos et al. (2007) and Pereira et al. (2006) also found higher values of CP in Mombasa grass $(57.2 \mathrm{~g} / \mathrm{kg})$ than in signalgrass $(38.0 \mathrm{~g} / \mathrm{kg})$. There was a linear increase of $\mathrm{CP}$ in the silage of Mombasa with the increment of the $\mathrm{N}$ dose. This increase is likely due to greater tillering and the consequent increase in the number of leaves per tiller in Mombasa grass relative to signalgrass. There was no effect $(\mathrm{P}>0.05)$ of nitrogen dose on crude protein content in signalgrass silage.

Evaluating the effect of $\mathrm{N}$ doses in silages, higher values $(\mathrm{P}<0.05)$ of NDF and ADF were found in the silages of Mombasa grass fertilized with 60 and $90 \mathrm{~kg} \mathrm{~N} / \mathrm{ha}$. This result is likely due to the larger size of the Mombasa grass (compared with signalgrass), which requires a greater amount of fiber to support the plant.

In the deployment of the interaction between grass and different $\mathrm{N}$ doses, there was an effect on the Mombasa grass for the contents of NDF and ADF, whose data were fit by quadratic models. The maximum NDF was $703.7 \mathrm{~g} / \mathrm{kg}$ at the dose of $72.35 \mathrm{~kg} \mathrm{~N}$, and the minimum ADF was $411.7 \mathrm{~g} / \mathrm{kg}$ at the dose of $39.14 \mathrm{~kg} \mathrm{~N}$. The fiber content of both silages

Table 2 - Chemical composition of silages of Mombasa grass and signalgrass

\begin{tabular}{|c|c|c|c|c|c|c|c|}
\hline \multirow{2}{*}{ Grasses } & \multicolumn{4}{|c|}{ Doses of nitrogen $(\mathrm{kg} / \mathrm{ha})$} & \multirow{2}{*}{ CV $(\%)$} & \multirow{2}{*}{ Regression equations } & \multirow{2}{*}{$\mathrm{R}^{2}$} \\
\hline & 0 & 30 & 60 & 90 & & & \\
\hline \multicolumn{5}{|c|}{ Dry matter $(\mathrm{g} / \mathrm{kg})$} & 2.34 & & \\
\hline Signalgrass & $220.3 \mathrm{a}$ & $220.5 \mathrm{a}$ & $209.4 \mathrm{a}$ & $199.7 \mathrm{a}$ & & $\hat{Y}=22.34375-0.024333 X$ & 0.89 \\
\hline \multicolumn{5}{|c|}{ Crude protein (g/kg DM) } & 5.43 & & \\
\hline Mombasa & $51.7 \mathrm{a}$ & $52.8 \mathrm{a}$ & $61.5 \mathrm{a}$ & $60.5 \mathrm{a}$ & & $\hat{Y}=4.94625+0.014375 X$ & 0.85 \\
\hline \multicolumn{5}{|c|}{ Neutral detergent fiber (g/kg DM) } & 1.81 & & \\
\hline Mombasa & $682.2 \mathrm{a}$ & $700.9 \mathrm{a}$ & $720.6 \mathrm{a}$ & $717.4 \mathrm{a}$ & & $\hat{Y}=67.94725+0.125117 X-0.000889 X^{2}$ & 0.89 \\
\hline Signalgrass & $699.9 \mathrm{a}$ & $700.0 \mathrm{a}$ & $693.4 b$ & $696.4 \mathrm{~b}$ & & & \\
\hline \multicolumn{5}{|c|}{ Acid detergent fiber (g/kg DM) } & 3.02 & & \\
\hline Mombasa & $370.3 \mathrm{a}$ & $365.3 \mathrm{a}$ & $419.9 \mathrm{a}$ & $402.9 \mathrm{a}$ & & $\hat{Y}=36.376625+0.080888 X-0.000334 X^{2}$ & 0.58 \\
\hline
\end{tabular}

$\mathrm{CV}$ - coefficient of variation.

Means followed by different letters in the columns differ $(\mathrm{P}<0.05)$ by the $\mathrm{F}$ test. 
was close to the values indicated by Santos (2007), who found NDF and ADF values of $640.0 \mathrm{~g} / \mathrm{kg}$ and $324.0 \mathrm{~g} / \mathrm{kg}$ and $622.0 \mathrm{~g} / \mathrm{kg}$ and $407.0 \mathrm{~g} / \mathrm{kg}$ for the silages of Mombasa grass and signalgrass, respectively. According to Wilman et al. (1976), the effect of nitrogen fertilization on the fiber components of the plants is not consistent.

There was a lower WSC content in the silages of signalgrass plants fertilized with $60 \mathrm{~kg}$ of $\mathrm{N}$, while at the other doses a lower content was observed in the silages of Mombasa grass. This behavior indicates the better utilization of WSC by LAB in Mombasa silages. Nkosi et al. (2010) found best efficiency in the use of WSC with the addition of microbial inoculants in the silage. However, this hypothesis does not seem to have support because the Mombasa grass silages were stabilized at a higher $\mathrm{pH}$ than the signalgrass silages. A quadratic effect $(\mathrm{P}<0.05)$ was observed in the WSC content of both grasses by the doses of $\mathrm{N}$, with an estimated maximum value of $16.4 \mathrm{~g} / \mathrm{kg}$ at the dose of $52.28 \mathrm{~kg} \mathrm{~N}$ for the Mombasa grass and minimum of $13.2 \mathrm{~g} / \mathrm{kg}$ at the dose of $52.30 \mathrm{~kg} \mathrm{~N}$ for signalgrass. The increase in the WSC content with higher doses of $\mathrm{N}$ observed in the Mombasa grass can be considered atypical and was possibly caused by methodological errors.

The $\mathrm{pH}$ and losses by gases were influenced $(\mathrm{P}<0.05)$ only by the forage species (Table 3 ). For the $\mathrm{NH}_{3}-\mathrm{N}$ content and losses by effluents, there was effect of the interaction $(\mathrm{P}<0.05)$ of forage species $\times$ doses of $\mathrm{N}$. Compared with the signalgrass, a higher value of $\mathrm{pH}$ was observed in the silage of Mombasa grass $(4.91 \times 4.50)$. This is probably due to the lower content of WSC in the Mombasa grass compared with the signalgrass $(30.4 \times 36.4 \mathrm{~g} / \mathrm{kg})$, although this difference is small. The WSC content supports the growth of LAB, which produces lactic acid, the main acid responsible for the rapid lowering of the $\mathrm{pH}$. The high values of $\mathrm{pH}$ and low DM content in these silages are indicative of favorable conditions for the growth of bacteria of the genus clostridium. The increase in the buffering capacity caused by proteolysis, which releases ammonia, hinders the fast decrease in $\mathrm{pH}$ (McDonald et al. 1991). It is also well known that the silages of tropical grasses stabilize at high $\mathrm{pH}$. However, $\mathrm{pH}$ alone cannot be considered a reliable criterion for the evaluation of silage because its inhibitory effect on bacteria and enzymes in plants depends on the rate of decline, ionic concentration and level of humidity in the environment.

Regarding the effect of the $\mathrm{N}$ dose on the forage species, there were higher contents of $\mathrm{NH}_{3}-\mathrm{N}$ in the silages of Mombasa grass fertilized with 60 and $90 \mathrm{~kg} \mathrm{~N} / \mathrm{ha}$. A quadratic effect was observed on content of ammonia in Mombasa grass as a function of $\mathrm{N}$ doses, yielding maximum level of $20 \% \mathrm{NH}_{3}-\mathrm{N}$ at a dose of $80.9 \mathrm{~kg} \mathrm{~N}$. Mahanna (1994) established that silages of grasses and legumes with $\mathrm{NH}_{3}-\mathrm{N}$ (total $\% \mathrm{~N}$ ) contents of $10-15 \%$ are considered of good quality. Based on this criterion, it appears that only the Mombasa grasses fertilized with 60 and $90 \mathrm{~kg} \mathrm{~N} / \mathrm{ha}$ exhibit higher $\mathrm{NH}_{3}-\mathrm{N}$ values than those recommended by Mahanna (1994). This result is likely explained by the low DM content of these silages, which might have favored the development of proteolytic microorganisms. According to Muck (1987), proteolysis rates in the formation of ammonia nitrogen are higher in silages with a reduced content of DM.

In plants fertilized with $\mathrm{N}$, a greater $(\mathrm{P}<0.05)$ production of effluents was observed in the silages of Mombasa grass. This result is possibly due to the lower DM content of these silages, which favored the production of effluent. However, this behavior is not completely understood because the plants of both species had very similar DM contents. It should also be noted that at the different $\mathrm{N}$ doses evaluated, both species exhibited DM contents lower than the $25 \%$ for good fermentation and reduction of losses by effluents recommended by McDonald et al. (1991). Bernardes (2006) found losses by effluents of $68.5 \mathrm{~kg} / \mathrm{t}$ in the silage of Marandu grass with $17.8 \%$ of DM, while Pereira et al. (2006) observed losses of $35.3 \mathrm{~kg} / \mathrm{t}$ in the silage of Mombasa grass with $21.24 \%$ of DM.

Table 3 - Mean $\mathrm{pH}$, ammonia, loss by effluent and loss by gases of the silages

\begin{tabular}{|c|c|c|c|c|c|c|}
\hline \multirow{2}{*}{ Silages } & \multicolumn{5}{|c|}{ Doses of nitrogen $(\mathrm{kg} / \mathrm{ha})$} & \multirow{2}{*}{$\mathrm{CV}(\%)$} \\
\hline & 0 & 30 & 60 & 90 & Means & \\
\hline & \multicolumn{5}{|c|}{$\mathrm{pH}$} & 2.97 \\
\hline Mombasa & 4.77 & 4.86 & 5.04 & 4.98 & $4.89 \mathrm{a}$ & \\
\hline \multirow[t]{2}{*}{ Signalgrass } & 4.58 & 4.38 & 4.62 & 4.48 & $4.51 \mathrm{~b}$ & \\
\hline & \multicolumn{5}{|c|}{$\mathrm{NH}_{3}-\mathrm{N}(\%$ total $\mathrm{N})$} & 23.59 \\
\hline Mombasa & $9.98 \mathrm{a}$ & $10.96 \mathrm{a}$ & $20.75 a$ & $16.72 \mathrm{a}$ & 14.60 & \\
\hline \multirow[t]{2}{*}{ Signalgrass } & $11.82 \mathrm{a}$ & $10.87 \mathrm{a}$ & $12.30 \mathrm{~b}$ & $11.47 \mathrm{~b}$ & 11.61 & \\
\hline & \multicolumn{5}{|c|}{ Effluent (kg/t NM) } & 12.08 \\
\hline Mombasa & $15.70 \mathrm{a}$ & $19.59 \mathrm{a}$ & $78.39 \mathrm{a}$ & $42.85 \mathrm{a}$ & 39.13 & \\
\hline \multirow[t]{2}{*}{ Signalgrass } & $15.67 \mathrm{a}$ & $13.46 \mathrm{~b}$ & $15.79 b$ & $19.93 b$ & 16.21 & \\
\hline & \multicolumn{5}{|c|}{ Gases (\%DM) } & 48.43 \\
\hline Mombasa & 4.64 & 3.01 & 4.76 & 6.26 & $4.67 \mathrm{a}$ & \\
\hline \multirow[t]{3}{*}{ Signalgrass } & 2.96 & 3.44 & 3.61 & 2.77 & $3.19 b$ & \\
\hline & \multicolumn{5}{|c|}{ Regression equations } & \\
\hline & & & $\mathrm{N}-\mathrm{NH}_{3}$ & & & $\mathrm{R}^{2}$ \\
\hline \multirow[t]{2}{*}{ Mombasa } & \multicolumn{5}{|c|}{$\hat{Y}=8.846+0.225408 X-0.001393 X^{2}$} & 66.71 \\
\hline & \multicolumn{5}{|c|}{ Effluent } & $\mathrm{R}^{2}$ \\
\hline Mombasa & \multicolumn{5}{|c|}{$\hat{Y}=8.236125+1.453287 X-0.010953 X^{2}$} & 55.2 \\
\hline
\end{tabular}


There was higher $(\mathrm{P}<0.05)$ gas loss in the Mombasa grass silage compared with signalgrass $(4.67 \times 3.19 \%)$ silage. These losses are associated with the type of fermentation that occurred during the process. Losses are lower when fermentation occurs via homofermentative bacteria using glucose as a substrate to produce lactic acid. When this process occurs by use of glucose or fructose, the $\mathrm{CO}_{2}$ and alcohol (ethanol and mannitol) production and losses by gas are considerable. This type of fermentation is performed by heterofermentative bacteria, enterobacteria and yeasts (McDonald et al., 1991).

According to the profile of fermentation of carbohydrates (Table 4), the isolated strains were identified. The species Lactobacillus. fermentum was identified as being predominant in plants of the evaluated grasses (Table 5).

All isolates were positive for the Gram test and negative for the catalase enzyme test. None of the isolates grew at $\mathrm{pH} 9.6$, but all of the isolates grew at 15 and $45^{\circ} \mathrm{C}$.

Table 4 - Fermentation standard of isolated strains from signalgrass and mombasa grass of lactobacillus genus

\begin{tabular}{|c|c|c|c|c|c|c|c|c|c|c|}
\hline & \multicolumn{10}{|c|}{ Isolated strain } \\
\hline & M1 & M2 & M4 & M16 & M17 & M21 & B3 & B4 & B5 & B6 \\
\hline Glycerol & - & - & - & - & - & - & - & - & - & - \\
\hline D-arabinose & - & - & - & - & - & - & - & - & - & - \\
\hline L-arabinose & + & + & - & - & - & - & $(+)$ & - & + & + \\
\hline Ribose & $(+)$ & + & - & + & + & + & + & - & + & + \\
\hline D-xylose & + & + & - & - & - & - & - & - & + & - \\
\hline B-methyl D-xyloside & - & - & - & - & - & - & - & - & - & - \\
\hline Galactose & $(+)$ & + & + & + & + & + & + & + & - & + \\
\hline D-glucose & + & + & + & + & + & + & + & + & - & + \\
\hline D-fructose & + & + & - & + & + & + & $(+)$ & - & + & - \\
\hline D-mannose & + & + & - & + & + & + & $(+)$ & - & + & - \\
\hline L-sorbose & - & - & - & - & - & - & - & - & - & - \\
\hline Sorbitol & - & - & - & - & - & - & - & - & - & - \\
\hline$\alpha$-methyl D-mannose & + & + & - & - & - & - & - & - & - & - \\
\hline$\alpha$-methyl D-glycoside & - & - & - & - & - & - & + & - & - & - \\
\hline $\mathrm{N}$-acetyl-glucosamine & + & + & - & - & + & + & $(+)$ & & - & - \\
\hline Amygdalin & + & + & - & $(+)$ & $(+)$ & + & - & - & - & - \\
\hline Arbutin & - & + & - & $(+)$ & $(+)$ & + & - & - & - & - \\
\hline Esculin & + & + & - & + & + & + & - & - & - & - \\
\hline Salicin & + & + & - & $(+)$ & $(+)$ & + & - & - & - & - \\
\hline Cellobiose & + & + & - & + & + & + & - & - & - & - \\
\hline Maltose & - & - & + & + & + & - & + & + & + & + \\
\hline Lactose & - & - & + & - & - & - & $(+)$ & - & - & - \\
\hline Melibiose & - & - & + & - & - & - & + & + & - & + \\
\hline$\beta$-gentibiose & + & + & - & + & + & + & + & - & - & - \\
\hline D-turanose & - & - & - & - & - & - & + & - & - & - \\
\hline L-lyxose & - & - & - & - & - & - & - & - & - & - \\
\hline D-tagatose & + & + & - & - & - & - & - & - & - & - \\
\hline D-fucose & - & - & - & - & - & - & - & - & - & - \\
\hline L-fucose & - & - & - & - & - & - & - & - & - & - \\
\hline D-arabitol & - & - & - & - & - & - & - & - & - & - \\
\hline L-arabitol & - & - & - & - & - & - & - & - & - & - \\
\hline Gluconate & - & - & - & $(+)$ & + & + & + & + & + & - \\
\hline 2Cetogluconate & - & - & - & - & - & - & - & - & - & - \\
\hline 5Cetogluconate & - & - & - & - & - & - & - & - & + & - \\
\hline
\end{tabular}

+ Intense fermentation; - No fermentation; (+) Low intense fermentation. 
Lactic acid bacteria strains, including Leuconostoc mesenteroides, are commonly found in plant cultures (Mundt et al., 1967; Mundt 1970). Guilherme et al. (2009) evaluated the lactic acid production of Leuconostoc mesenteroides in cashew syrup and found $15.5 \mathrm{~g} / \mathrm{L}$ of lactic acid, whereas the production was compromised in values with a $\mathrm{pH}$ under 4.3. This $\mathrm{pH}$ value is close to those found in grass silages, indicating that these LAB may contribute to the decrease in $\mathrm{pH}$.

According to Hu et al. (2007), Pediococcus pentosaceus is of scientific interest because of its ability to produce antimicrobial agents (bacteriocins). This production makes Pediococcus pentosaceus a possibility for use in food preservation. Wang \& Nishino (2009) found L. fermentum in silage containing sudangrass after 14 and 56 days of ensiling.

According to Hounhouigan et al. (1993) and Halm et al. (1996), L. fermentum has been found to be the predominant microorganism in fermented products of cereals. Calderon et al. (2003) observed that this microorganism has the ability to use starch as a substrate by producing $\alpha$-amylase and that it is classified as an amylolytic lactic acid bacteria (ALAB). These microorganisms have been isolated from different kinds of tropical foods with a high starch content (Nwankwo et al., 1989; Olympia et al., 1995; Morlon-Guyot et al., 1998). In natural fermentation, ALAB can increase the availability of carbohydrates that have been rapidly fermented by partial hydrolysis of starch, provided that their $\alpha$-amylase is able to hydrolyze these granules (Rodriguez Sanoja et al., 2000). The association of L. fermentum with L. buchneri increased the aerobic stability of silage with high humidity (Wang \& Nishino, 2010). Adesogan et al. (2003) reported that inoculating the species of L. fermentum alone has less effect than when it is combined with other species. Wang \& Nishino (2010) concluded that L. fermentum was predominant in nonensiled material, while L. brevis and L. buchneri became prevalent during the fermentation process. Tjandraatmadja

Table 5 - Species identification by the API $50 \mathrm{CH}$ test, with respective identification percentages

\begin{tabular}{lrc}
\hline Code & Identified species of bacteria & \% Identification \\
\hline B4 & Lactobacillus fermentum & 99.5 \\
B6 & Lactobacillus fermentum & 96.2 \\
M4 & Lactobacillus fermentum & 93.7 \\
M16 & Lactobacillus paracasei ssp paracasei & 80.8 \\
M21 & Lactobacillus paracasei ssp paracasei & 80.8 \\
M2 & Lactobacillus bactis ssp lactis & 82.8 \\
B5 & Lactobacillus brevis & 70.5 \\
M17 & Lactobacillus plantarum & 94.9 \\
M1 & Pediococcus pentosaceus & 93.5 \\
B3 & Leuconostoc mesenteroides ssp & 88.9 \\
\hline
\end{tabular}

et al. (1994) found significant quantities of L. fermentum in Panicum maximum cv. Hamil.

In other studies, Pereira et al. (2007), assessed the populations of lactic acid bacteria in plants of elephant grass cv. Cameroon and identified the isolates as Lactobacillus casei ssp. pseudo plantarum. Santos (2007) identified the prevailing isolates in Mombasa grass as Lactobacillus plantarum, using the carbohydrate fermentation profile as a criterion for identification. Based on the above account, the dominant species of LAB is different between various cultures.

In fresh forage, LAB populations of 4.69 and $5.65 \mathrm{log}$ $\mathrm{cfu} / \mathrm{g}$ were recorded for signalgrass and Mombasa grass, respectively. In the silages, $\mathrm{LAB}$ populations ranged from 4.95 to $6.95 \mathrm{log} \mathrm{cfu} / \mathrm{g}$ (Table 6). Lactic-acid bacteria values found for the fresh grass in the present experiment are similar to the values observed by Pereira et al. (2006) for Mombasa grass (5.55 $\log \mathrm{cfu} / \mathrm{g}$ ). The value observed for signalgrass is lower than the $5.51 \log \mathrm{cfu} / \mathrm{g}$ reported by Souza et al. (2006). However, these values are within the limits of variation observed by Pahlow et al. (2003) for temperate climate grasses. The increase in the population of LAB in silages compared with fresh forage is commonly observed in most studies with silages. This increase in the $\mathrm{LAB}$ population is due to the reactivation of dormant and non-culturable LAB cells during the process of chopping the forage (Pahlow et al., 2003).

Muck (1991), suggested that LAB populations larger than $5 \mathrm{log} \mathrm{cfu} / \mathrm{g}$ are the minimum necessary to ensure the good fermentation of the silage. It appears that only the Mombasa grass reached this value, and it might compromise the conservation process through the lower production of acids that are needed to stabilize the silage process. The

Table 6 - Quantification of lactic acid bacteria (LAB), enterobacteria, filamentous fungi and yeasts of Mombasa grass and signalgrass before ensilage and of the respective silages

\begin{tabular}{lccc}
\hline Before ensilage & LAB & Enterobacteria & Fungi and yeasts \\
\hline \multirow{3}{*}{ Signalgrass } & 4.69 & $(\log \mathrm{cfu} / \mathrm{g})$ \\
Mombasa & 5.65 & 7.55 & 3.65 \\
Doses of N & & 7.65 & 3.39 \\
0 & & Signalgrass silage \\
30 & 5.39 & Not detected & 2.00 \\
60 & 5.57 & Not detected & 2.00 \\
90 & 5.23 & Not detected & 2.17 \\
& 4.95 & Not detected & 2.17 \\
0 & & Mombasa silage & \\
30 & 6.70 & Not detected & 2.30 \\
60 & 6.95 & Not detected & 1.74 \\
90 & 5.95 & Not detected & 2.30 \\
& 6.17 & Not detected & 2.30 \\
\hline
\end{tabular}


low content of $\mathrm{CHO}$ in the fresh plants possibly limited the LAB population growth in silages. The LAB population demonstrated a decreasing trend with increasing $\mathrm{N}$ doses. This behavior differs from the behavior observed by Brady (1965) and Wilson (1969), who reported an increase in the LAB population with higher nitrogen doses. This result is possibly due to the increase in $\mathrm{N}$ doses, with which the CP content in grasses is elevated, thus increasing the availability of the essential amino acids for the growth of LAB (Brady, 1965). Because of the large number of microorganisms involved, the ensiling process is complex and can be considered a metabiosis. That is, a simultaneous and successive development of microorganisms of various genera and species occurs, depending mainly on the $\mathrm{pH}$, the oxidation-reduction potential and the type and amount of substrates present in the environment (Pereira $\&$ Santos, 2006). Thus, the microbial population of forage culture before ensiling is completely numerically and taxonomically different from the microbial population found in the silage.

The number of enterobacteria (ENT) in the fresh plants did not differ between forage species, averaging $7.60 \log \mathrm{cfu} / \mathrm{g}$. This value is similar to that found by Sousa et al. (2006) in signalgrass collected at 60 days of regrowth $(7.08 \mathrm{log} \mathrm{cfu} / \mathrm{g})$. The higher ENT population compared with that of LAB is not desired, but has been reported frequently in the literature (Pahlow et al., 2003; Santos, 2007). Given their facultative anaerobic nature, the presence of enterobacteria in silages is not desirable. Enterobacteria compete with LAB for nutrients before and after ensiling. Furthermore, they are responsible for most of the ammonia formed from the degradation of protein and nitrate reduction, and they promote increase in the buffering capacity of the ensiled mass (Pereira et al., 2006). Compared with $\mathrm{LAB}$, enterobacteria are more sensitive to $\mathrm{pH}$. Thus, the presence of ENT in the silage depends mainly on the time required for the $\mathrm{LAB}$ to be able to produce a sufficient amount of acid to lower the $\mathrm{pH}$ to values toxic to ENT. In good quality silages, the enterobacteria population is no longer observed after seven days of fermentation; however, in silages with a high moisture and low concentration of soluble carbohydrates, the ENT population can compete for the substrate with $\mathrm{LAB}$ for more than 30 days of fermentation (Luiz \& Ramirez, 1988). Because the silos were opened 90 days after fermentation, the ENT population was not detected.

The population of fungi and yeasts was similar among the fresh grasses. There was a reduction in the population of fungi and yeasts during the fermentation process in both forage species, with an average 2.08 and $2.16 \mathrm{log} \mathrm{cfu} / \mathrm{g}$ in the silages of signalgrass and Mombasa grass, respectively. These values are similar to those found by Pereira et al. (2007) in the silage of elephant grass (3.25).

\section{Conclusions}

Nitrogen fertilization reduces the dry matter and soluble carbohydrate contents of silages of Mombasa grass and signalgrass forages without compromising their fermentation profiles. Lactobacillus fermentum is the predominant species of lactic bacteria in both grasses.

\section{Acknowledgments}

The authors thank FAPEMIG, INCT-CA and CNPq (Conselho Nacional de Desenvolvimento Científico e Tecnológico) for the financial support.

\section{References}

ADESOGAN, A.T.; SALAWU, M.B.; ROSS, A.B. et al. Effect of Lactobacillus buchneri, Lactobacillus fermentum, Leuconostoc mesenteroides inoculants, or a chemical additive on the fermentation, aerobic stability, and nutritive value of crimped wheat grains. Journal of Dairy Science, v.86, p.1789-1796, 2003.

AGRIPOINT. 2007. Pesquisa Top BeefPoint de confinamentos: Os 50 maiores confinamentos do Brasil em 2006. Available at: $<$ http://wm.agripoint.com.br/imagens/banco/beefpoint/Top50 2006 07.pdf> Accessed on: Apr. 15, 2012.

ALEXANDRINO, E.; MOSQUIM, P.R.; NASCIMENTO JÚNIOR, D. et al. Evolução da biomassa e do perfil da reserva orgânica durante a rebrotação da Brachiaria brizantha cv. Marandu submetida a doses de nitrogênio. Revista Brasileira de Saúde e Produção Animal, v.9, n.2, p.190-200, 2008.

BERNARDES, T.F. Controle da deterioração aeróbica de silagens. 2006. 103f. Tese (Doutorado em Zootecnia) - Universidade Estadual Paulista/Faculdade de Ciências Agrárias e Veterinária, Jaboticabal.

BOLSEN, K.K.; LIN, C.; BRENT, B.E. et al. Effect of silage additives on the microbial succession and fermentation process of alfalfa and corn silages. Journal of Dairy Science, v.75, n.11, p.3066-3083, 1992.

BRADY, C.J. On the nitrogen nutrition of silage strains of lactic acid bacteria. Australian Journal of Biological Science, v.19, n.1, p.105-122, 1965.

CAI, Y.; OHMOMO, S. Effect of lactic acid bacteria and cellulose on the changes in microflora during fermentation, gas production and dry matter loss in silage. Animal Science and Technology, v.66, n.11, p.941-948, 1995.

CALDERON, M.; LOISEAU, G.; GUYOT, J.P. Fermetation by Lactocillus fermentum Ogi E1 of different combinations of carbohydrates occurring naturally in cereals: consequences on growth energetic and $\alpha$-amylase production. Internation Journal of Food Microbiology, v.80, p.161-169, 2003.

CEZÁRIO, A.S. Perdas na ensilagem e desempenho de bovinos de corte suplementados com dietas contend silagem de capimmarandu em duas idades de rebrotação com inoculante bacteriano. 2011. 84f. Tese (Doutorado em Zootecnia) Universidade Federal de Viçosa, Viçosa, MG.

COLOZZA, M.T.; KIEHL, J.C.; WERNER, J.C. et al. Respostas de Panicum Maximum cultivas aruana a doses de nitrogênio. Boletim de Indústria Animal, v.57, n.1, p.21-32, 2000. 
De MAN, J.C.; ROGOSA, M.; SHARPE, M.E. A medium for the cultivation of lactobacilli. Journal of Applied Bacteriology, v.23 p.130-135, 1960.

FERREIRA, D.F. Sistema de análises de variância para dados balanceados. Lavras: UFLA, 2000. (SISVAR 4. 1. Pacote computacional).

GONÇALVES, J.S.; NEIVA, J.N.M.; VIEIRA, N.F. et al. Valor nutritivo de silagens de capim elefante (Pennisetum purpureum Schum.) com adição de diferentes níveis dos subprodutos do processamento de acerola (Malpighia glabra L.) e de goiaba (Psidium guajava L.). Revista Ciência Agronômica, v.35, n.1, p.131-137, 2004.

GUILHERME, A.A.; PINTO, G.A.S.; RODRIGUES, S. Avaliação da produção de ácido lático por Leuconostoc mesenteroides B512F em xarope de caju. Ciência e Tecnologia de Alimentos, v.29, n.4, p.738-743, 2009.

HALM, M.; OSEI-YAW, A; HAYFORD, A. et al. Experiences with the use of a starter culture in the fermentation of maize for "kenkey" production in Ghana. World Journal of Microbiology and Biotechnology, v.12, p.531-536, 1996.

HOUNHOUIGAN, D.J.; NOUT, M.J.R.; NAGO, C.M. et al. Composition and microbiological and physical attributes of maws a fermented maize dough from Benin. International Journal of Food Science \& Technology, v.28, p.513-517, 1993.

HU, Y.; XIA, W,; GE, C. Effect of mixed starter cultures fermentation on the characteristics of silver carp sausages. World Journal of Microbiology \& Biotechnology, v.23, p.1021-1031, 2007.

JOHNSON, R.R.; BLAWANI, T.L.; JOHNSON, L.J. et al. Corn plant maturity. Effect on in vitro cellulose digestibility and soluble carbohydrate content. Journal of Animal Science, v.25, n.2, p.617-623, 1966.

JOHNSON, C.R.; REILING, B.A.; MISLEVY, P. et al. Effects of nitrogen fertilization and harvest date on yield, digestibility, fiber, and protein fractions of tropical grasses. Journal of Animal Science, v.79, p.2439-2448, 2001.

KEADY, T.W.J.; MAYNE, C.S. The effects of nitrogen fertilizer, harvest date and additive treatment on fermentation, in-silo losses and predicted feeding value of grass silage. In: INTERNATIONAL SILAGE CONFERENCE, 11., Aberystwyth, Wales, 1996. Proceedings... Aberystwyth, Wales, 1996. p.52-53.

KEADY, T.W.J.; MURPHY J.J.; FITZGERALD, S. The effects of level of nitrogen fertilizer application to silage swards on subsequent silage composition, intake and animal performance of lactating dairy cattle. Journal of Animal Science, v.60, p.515, 1995.

KEADY, T.W.J.; O'KIELY, P. An evaluation of potassium and nitrogen fertilization and date of harvest on fermentation, effluent production, dry matter recovery and predicted feeding value of silage. Grass and Forage Science, v.53, p.326-337, 1998.

KEADY, T.W.J.; O'KIELY, P. An evaluation of the effects of rate of nitrogen fertilization of grassland on silage fermentation, insilo losses, effluent production and aerobic stability. Grass and Forage Science, v.51 p.350-362, 1996.

KEADY, T.W.J.; MAYNE, C.S; FITZPATRICK, D.A. Prediction of silage feeding value from the analysis of the herbage at ensiling and effects of nitrogen fertilizer, date of harvest and additive treatment on grass silage composition. Journal of Agricultural Science, v.134, p.353-368, 2000.

KEADY, T.W.J.; KILPATRICK, D.J.; MAYNE, C.S. et al. Effects of replacing grass silage with maize silages, differing in maturity, on performance and potential concentrate sapring effect of dairy cows offered two feed value grass silages. Livestock Science, v.119, n.1, p.1-11, 2008.

LUIZ, L.; RAMIREZ, M. Evolución de la flora microbiana en ensilaje de king grass. Pastos y Forrajes, v.11, p.249-253, 1988

MAGALHÃES, J.A.; LOPES, E.A.; RODRIGUES, B.H.N. et al. Influência da adubação nitrogenada e da idade de corte sobre o rendimento forrageiro do capim-elefante. Revista Ciência Agronômica, v.37, n.1, p.91-96, 2006.
MAGAlHÃES, A.F.; PIRES, A.J.V.; CARVALHO, G.G.P. et al. Composição bromatológica e concentrações de nutrientes do capim braquiária adubado com nitrogênio e fósforo. Revista Brasileira de Saúde e Produção Animal, v.12, n.4, p.893-907, 2011.

MAHANNA, B. Proper management assures high-quality silage, grains. Feedstuffs, n.10/17, p.12-56, 1994.

McDONALD, P.; HENDERSON, N.; HERON, S. The biochemistry of silage. Marlow Bucks: Chalcombe Publications, 1991. 340p.

MORLON-GUYOT, J.; GUYOT, J.P.; POT, B. et al. Lactobacillus manihotivorans sp. nov., a new starch-hydrolyzing lactic acid bacterium isolated from cassava sour starch fermentation. International Journal of Systematic Bacteriology, v.48, p.1101-1109, 1998.

MUCK, R.E. Dry matter level affects alfalfa silage quality I. Nitrogen transformations. American Society of Agricultural and Biological Engineers (ASABE), v.30, n.1, p.7-14, 1987.

MUCK, R.E. Silage fermentation. In: Mixed cultures in biotechnology. New York: McGrow Hill Inc, 1991. p.171-204.

MUNDT, J.O. Lactic acid bacteria associated with raw plant food material. Journal of Milk and Food Technology, v.33, p.550-553, 1970.

MUNDT, J.O; GRAHAM, W.F.; McCARTY, I.E. Spherical lactic acid producing bacteria of southern-grown raw and processed vegetables. Journal of Applied Microbiology, v.15, p.1303-1308, 1967.

NAMIHIRA, T.; SHINZATO, N.; AKAMINE, H. et al. Influence of nitrogen fertilization on tropical-grass silage assessed by ensiling process monitoring using chemical and microbial community analyses. Journal of Applied Microbiology, v.108, p.1954-1965, 2009.

NKOSI, B.D.; MEESKE, R.; VAN DER MERWE, H.J. et al. Effects of homofermentative and heterofermentative bacterial silage inoculants on potato hash silage fermentation and digestibility in rams. Animal Feed Science and Technology, v.157, n.3-4, p.195-200, 2010.

NWANKWO, D.; ANADU, E.; USORO, R. Cassava-fermenting organisms. MIRCEN Journal of Microbiology and Biotechnology, v.5, p.169-179, 1989.

OLYMPIA, M.; FUKUDA, H.; ONO, H. et al. Characterization of starch-hydrolysing lactic acid bacteria isolated from a fermented fish and rice food, Burong Isdas and its amylolytic enzyme. Journal of Fermentation and Bioengineering, v.80, p.124-130, 1995.

PAHLOW, G.; MUCK, R.E.; DRIEHUIS, F. Microbiology of ensiling. In: SILAGE SCIENCE AND TECHNOLOGY, Madison. Proceedings... Madison: ASCSSA-SSSA, Agronomy, 2003. v.42, p.31-93.

PAULY, T.M.; HANSSON, I.B.; THAM, W.A. The effect of mechanical forage treatments on the growth of Clostridium tyrobutyricum and Listeria monocytogenes in grass silage. Animal Feed Science and Technology, v.78, p.127-139, 1999.

PEREIRA, O.G.; ROCHA, K.; FERREIRA, C.L.F. Composição química, caracterização e quantificação da população de microrganismos em capim-elefante cv. Cameroon (Pennisetum purpureum, Schum.) e suas silagens. Revista Brasileira de Zootecnia, v.36, n.6, p.1742-1750, 2007.

PEREIRA, O.G.; SANTOS, E.M. Microbiologia e o processo de fermentação em silagens. In: SIMPÓSIO SOBRE MANEJO ESTRATÉGICO DA PASTAGEM, 3., 2006. Viçosa, MG. Anais... Viçosa, MG: UFV; DZO, 2006. 430p.

PEREIRA, O.G.; SANTOS, E.M.; FERREIRA, C.L.L.F. et al. Populações microbianas em silagem de capim-mombaça de diferentes idades de rebrotação. In: REUNIÃO ANUAL DA SOCIEDADE BRASILEIRA DE ZOOTECNIA, 43., João Pessoa. Anais... João Pessoa: UFPB, 2006. (CD-ROM).

RODRIGUEZ SANOJA, R.; MORLON-GUYOT, J.; JORE, J. et al. Comparative characterization of complete and truncated forms of Lactobacillus amylovorus a-amylase and the role of the C-terminal direct repeats in raw starch binding. Applied and Environmental Microbiology, v.66, p.3350-3356, 2000. 
SANTOS, E.M. Populações microbianas e perfil fermentativo em silagens de capins tropicais e desempenho de bovinos de corte alimentados com dietas contendo silagens de capim mombaça. 2007. 107f. Tese (Doutorado em Zootecnia) - Universidade Federal de Viçosa, Viçosa, MG.

SANTOS, E.M.; PEREIRA, O.G.; ROSA, L.O. Perfil fermentativo e composição bromatológica de silagens de capim-braquiária (Brachiaria decumbens cv. Basilisk) de diferentes idades de rebrotação. In: REUNIÃO ANUAL DA SOCIEDADE BRASILEIRA DE ZOOTECNIA, 44., 2007, Jaboticabal. Anais... Jaboticabal: SBZ, 2007 (CD-ROM).

SILVA, D.J.; QUEIRÓZ, A.C. Análise de alimentos: métodos químicos e biológicos. 3.ed. Viçosa, MG: UFV, 2002. 235p.

SOUZA, L.O.; SANTOS, E.M.; PENTEADO, D.C.S. et al. Composição bromatológica de silage de capim-mombaça inoculada com lactobacilus plantarum da microflora epifítica. In: CONGRESSO NACIONAL DE ZOOTECNIA- ZOOTEC, 2006, Recife. Anais... Recife: UFRPE, 2006. (CD-ROM).

TJANDRAATMADJA, M.; NORTON, B.W.; MAC RAE, I.C. Ensilage characteristics of three tropical grasses as influenced by stage of growth and addition of molasses. World Journal of Microbiology \& Biotechnology, v.10, p.74-81, 1994.
VAN SOEST, P.J.; ROBERTSON, N,J.B. Analysis of forages and fibrous food. 1.ed. Ithaca: Cornell University, 1985. 202p.

WANG, C.; NISHINO, N. Presence of sourdough lactic acid bacteria in commercial total mixed ration silage as revealed by denaturing gradient gel electrophoresis analysis. Applied Microbiology, v.51, n.4, p.436-442, 2010.

WANG, F.; NISHINO, N. Association of Lactobacillus buchneri with aerobic stability of total mixed ration containing wet brewers grains preserved as a silage. Animal Feed Science and Technology, v.149, p.265-275, 2009.

WILMAN, D. Nitrogen and Italian ryegrass. 1. Growth up to 14 weeks: dry matter yield and digestibility. Grass and Forage Science, v.30, p.141-147, 1975.

WILMAN, D.; KOOCHEKI, A.; LWOGA, A.B. The effect of interval between harvests and nitrogen application on the proportion and yield of crop fractions and on the digestibility and digestible yield and nitrogen content and yield of two perennial ryegrass varieties in the second harvest year. Journal of Agricultural Science, v.87, p.59-74, 1976.

WILSON, R.K. Effects of fertilizer N, additives and season on silage fermentation in laboratory silos. Irish Journal of Agricultural Research, v.8, p.307-318, 1969. 